\title{
Post-Covid-19 Recovery Policies: Place-based and Sustainable Strategies*
}

\author{
Richard Tuffs, Jan Larosse and Dimitri Corpakis ${ }^{* *}$
}

\begin{abstract}
The Corona-crisis is a wake-up call to make our way of life and our economy more resilient. While still struggling with the immediate impact of the crisis, policy makers are preparing an unprecedented investment effort to direct our economy to a new, sustainable future. The EU must develop leadership at all policy levels for the green, digital and white transitions. But rebooting the economy not only requires huge investment efforts, the 'what'. Equally important is the 'how', the way that the recovery strategy is designed, governed and implemented. Therefore, the Green Deal and industrial strategy must develop a multi-level governance model that engages cities and regions across Europe - the policy levels closest to both citizens and innovation ecosystems that deliver solutions for citizens' needs.

Drawing lessons from the Lisbon Strategy, the smart specialisation approach has been developed to prevent the fragmentation of investment efforts in the EU by prioritising innovation and transformation investment in Member States and regions in their competitive strengths. It is now a core component of EU Cohesion policy and is increasingly aligning specialisations in partnerships across borders. A new 'Marshall Plan' for EU recovery should take on board the role of place-based innovation and smart specialisation in regions and cities, to co-invest effectively in new EU value chains.
\end{abstract}

Keywords: Regional Development; Regions; Recovery; Smart Specialisation; Post Covid-19; Europe

\begin{abstract}
"[...] We should, however, start to prepare the measures necessary to get back to a normal functioning of our societies and economies and to sustainable growth, integrating inter alia the green transition and the digital transformation, and drawing all lessons from the crisis.

This will require a coordinated exit strategy, a comprehensive recovery plan and unprecedented investment. We invite the President of the Commission and the President of the European Council, in consultation with other institutions, especially the ECB,
\end{abstract}

\footnotetext{
* Invited article

*** Independent Experts, Friends of Smart Specialisation (d.corpakis@ gmail.com, jan.larosse@telenet.be, richardtuffs@ymail.com)
}

Edited by: Niccolò Cusano University

ISSN: 1593-0319

Tuffs, R., Larosse, J., \& Corpakis, D. (2020). Post-Covid-19 Recovery Policies: Place-based and Sustainable Strategies. Symphonya. Emerging Issues in Management (symphonya.unicusano.it), (2), 55-62.

http://dx.doi.org/10.4468/2020.2.06tuffs.larosse.corpakis 
to start work on a Roadmap accompanied by an Action Plan to this end $[\ldots]$ »

Joint statement of the Members of the European Council (Heads of State and Government), 26 March 2020.

\section{In Crisis Mode}

It is quite clear that urgent action is needed in Europe and globally to counteract the negative impacts of the Coronavirus pandemic. There will be a need for short term economic stimulus packages for businesses and support for workers. However, we are not alone in taking this opportunity ${ }^{1}$ to reflect on future changes and directions to European Union policies. The Coronavirus crisis is perhaps a 'tipping point' but the financial crash of 2008 was already a warning sign of the instability of the current economic and financial system. A new post-crisis vision for economic development is needed with a governance built on democratic values and social and economic solidarity. The undeniably crucial role of citizens in this crisis unveils the power of civil society to build resilience and because the regional and local levels are closest to citizens, this is a call for governance and leadership that involve all societal and economic stakeholders, and regions ${ }^{2}$ and cities in particular ${ }^{3}$.

\section{Changing Paradigm}

Since the financial crash that has seen a decade of catching up to the previous levels of GDP and living standards, we have been observing increasing inequality both within societies and between territories - a trend that is likely to be exacerbated by the health crisis. The rise of populism has shed light on the 'places that do not matter' (Rodríguez-Pose, 2018) ${ }^{4}$ starved of both public and private investment. At the European level this is leading to conflict between budget rigidity and cohesion. But the health crisis has dramatically twisted the order of priorities in budget policy.

Globalisation is not only perceived as out of control but also appears to be slowing

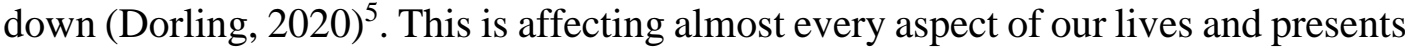
a huge challenge to the expectation of acceleration and unlimited growth. This slowdown is compounded by the need to act globally on the causes of climate change and the loss of biodiversity while dealing with technological progress in the digital sector such as artificial intelligence to find new sources of productivity growth. This process of structural change has already started as witnessed by the UN's Sustainable Development Goals and the European Green Deal - the new growth strategy for the $\mathrm{EU}^{6}$. The Communication introducing the Green Deal admits that this unprecedented transformation will 'require a strong policy response at all levels' and significant investment efforts.

It is important to note here that the Green Deal is supported by the EU's new Industrial Strategy ${ }^{7}$, which is another step in the evolution towards a new model for the EU economy of the 21st century. In a previous paper ${ }^{8}$, Friends of Smart Specialisation ${ }^{9}$ argued that the EU still has major assets to be a world leader in economic solutions for the big societal challenges, amongst these assets is its 'unity in diversity', but a new industrial strategy is required that ensures economic resilience 
in a time of structural change. The Industrial Strategy should provide a policy framework for long-term investment in transformation, a compass for confidence in a common future, conducted through multi-level governance of co-investments.

A new 'Marshall Plan' ${ }^{\text {'0 }}$ is envisaged to relaunch the economy on a sustainable development path, with a focus on re-organising the global supply chains. This strategy is happening as fiscal policy becomes the main driver of the recovery. However, to be successful, fiscal policy underpinning transformation also needs to align investment at EU, national and regional levels. But the institutional preconditions to develop and manage such a European transformation plan are not yet in place. We will have to build the bridge while walking on it.

At the macro-economic policy level, the persistent North-South divisions on budget policies can lead to inertia or worse. Therefore, the EU must put industrial policy at the heart of its recovery plan. But such a transformation policy must also unleash the potential and the dynamics of local economies, to enable their full deployment and successful integration. This calls for a policy combining EU-level strategic goals while also building the capacity of local and regional economies to achieve these European goals alongside regional priorities. Thus, there is a need for a place-based industrial policy shaped by the diversity of regions framed within a multi-level governance approach.

\section{What happened to the Regional and Local Dimensions?}

It is time to act but neither of the two Communications mentioned above ${ }^{11}$ addresses with any precision the spatial dimension and the mechanisms required to implement effectively the policies outlined in such a spatial and multi-level perspective on economic development. The regional and local dimensions are largely ignored even though it is at the regional and local level where policies hit the road. Policies affect places and territories differently, but territorial impacts are routinely not taken (enough) into account when shaping and implementing EU-level policies. Providing development opportunities to all, encouraging lead-regions to excel while also reducing inequalities between places will require targeted place sensitive policies, interventions and investments. These policies will involve industrial strategies that develop and support the forward-looking competitive advantages of the region or city.

Accepting place-based policies does not mean ignoring a top down approach. Responses to the current Coronavirus crisis, and the need for a global response to climate change, require 'big government' that sets common directions, just as more localised government is needed for specific implementation goals.

Therefore, a territorial dimension should be applied in EU policy making in general and relevant impact analyses should be developed that are place and area-specific and future oriented ${ }^{12}$. All EU policies need to reflect the diversity of needs and opportunities of individual places and communities and fully capitalise on their entrepreneurial capacity to position themselves in European value chains.

Hence, smart specialisation strategies make the difference. Without the proper prioritisation of resources for innovation and transformation in regions and cities no European recovery policy can work effectively. But we are not starting from scratch. 


\section{Regional Innovation Ecosystems and Smart Specialisation}

There is now a growing academic literature on regional innovation ecosystems (Fernandes et al., 2020) ${ }^{13}$ which argues that economic development is informed by the search for competitive advantage focused on innovation led by societal challenges. Innovation is thus an interactive process, socially and territorially embedded and linked to the culture, history and institutions of a region or city. Structural change can be managed more effectively through evolving triple or quadruple helix models of governance within strong regional innovation ecosystems that can manage joint priority setting and transregional and international interconnections.

Smart specialisation ${ }^{14}$ has become a powerful feature of current regional innovation and industrial policies in Europe. It is through effective smart specialisation strategies for each region in Europe that it is possible to combine a top down direction - green and digital transition - along with a focus on the competitive capacities of each region. Adopting smart specialisation in the governance of industrial strategy makes a fundamental difference for the success of transformation policies by:

1. anchoring industrial policy in real places and real ecosystems;

2. mobilising productivity increasing investments linked to international value chains;

3. co-financing innovation and transformation efforts by sourcing EU, national and regional funding;

4. reshoring strategic industrial activities;

5. promoting mutually beneficial economic cooperation between regions ${ }^{15}$.

Smart specialisation has been an ex-ante conditionality in Cohesion Policy since 2014 and will continue as an enabling condition in the next funding period 20212027 for Priority 1: A smarter Europe: innovative and smart economic transformation ${ }^{16}$. However, it is clear that smart specialisation has to go beyond cohesion and use the leverage of the single market (setting standards and pooling innovation services) for the transregional restructuring of value chains. This demands changes in governance capacity at both the regional and European level to develop robust transformation strategies and to monitor their implementation and impact. A recent report involving a survey of 35 smart specialisation implementation cases identified three major challenges:

1. the involvement of stakeholders in a continuous dialogue to drive the territorial innovation process;

2. the development of efficient innovation policy instruments to support the structural transformation of the economy at regional and/or national level;

3. the pursuit of the internationalisation of the regional/national economy as well as positioning in relevant European value chains ${ }^{17}$.

The success of this new generation of smart specialisation strategies for regional and European transformation objectives will depend on the capacity to induce 'smart complementarities' in a European multi-level governance model for industrial policy. This multi-level governance is exemplified by political leadership that seeks the convergence of fiscal policies in mobilizing resources for innovation and transformation in agreed priority domains. Smart specialisation thus enables synergies by aligning regional investments. 


\section{Priorities for Action}

Therefore, we call upon EU, national and regional policy makers to embrace regional smart specialisation strategies. These strategies will need to focus on new perspectives on globalisation such as the rethinking of supply chains and the shift towards both sustainable and resilient economies. This will require action at three levels.

Firstly, it is now important to build on a new sense of social solidarity and engage a wide range of stakeholders in an Entrepreneurial Discovery Process ${ }^{18}$ that can identify a region's competitive advantages and industrial transition to position the region in current and future European value chains. This provides a stronger impulse for effective multi-level governance which can help identify and combine funding sources from a range of public and private sources and seek synergies between (if not competing but often uncoordinated) funding streams. Political leadership in ambitious cities and regions shows in bold investments at local level as well as in necessary alliances for European solutions.

Secondly, more attention should be placed on the development of efficient innovation policy instruments to support the structural transformation of the economy at the regional and/or national level and on learning capacity. The need for a better evaluation of innovation and transformation policies has been long called for $^{19}$. Studies under regional innovation systems provide frameworks for actions leading to structural change. These frameworks provide for suggested activities depending on the type of regional economy and accept that there in no one size fits $\mathrm{all}^{20}$. However, two measures deserve more attention: firstly, moving research and innovation activities to the market more rapidly through improved upscaling involving investment in joint demonstration activities, etc., and secondly, paying more attention to embedding skills strategies within smart specialisation strategies. Furthermore, regions must also develop a 'learning capacity' in order to take an experimentalist learning approach to important investment decisions. This allows regions to continually monitor policies and outputs and adjust their smart specialisation strategies.

Thirdly, it is important that regions do not pursue an inward-looking approach. Economic transformation involves developing a bottom-up strategy based on competitive advantage in areas of future wealth, but is also increasingly linked to the search for 'smart complementarities' involving transnational collaboration as illustrated by the smart specialisation thematic platforms ${ }^{21}$ and regional networks such as the Vanguard Initiative ${ }^{22}$. This means more international networking at the European level supported by stronger European transnational cooperation programmes which are linked to the European strategic partnerships, missions and industrial policy.

\section{Conclusion}

A wide range of commentators now accept that we will move to a 'new normal'23. This implies political leadership shifting priorities: no longer accepting underfunded public sectors such as health care or economic systems that ignore ecological ceilings as normal. Neither should increased social and territorial inequality be part of the 
'new normal' because all places have unique assets that are needed to make the transition together.

The changes indicated above will require a strong coalition of the willing. This coalition will be formed by those that promote a collaborative approach to building resilient and sustainable economies across all regions and cities in Europe, based on new understanding of value creation through competition and cohesion. The development of resilient local economies is an essential component of the European model. A model that capitalises on its diversity and strong value chains to play a leading role in the multi-bloc world-order of the global economy, imposing its standards and values and ensuring its strategic autonomy.

Regional policy, at EU and some nation state levels, has typically been pursued as a distinct strand of activity outside of the mainstream of overall policy ${ }^{24}$. Sectoral policies such as research and innovation are 'place-neutral'. This has meant that they have often ignored territorial impact and the potential of spaces ${ }^{25}$. There is an urgent need to find the correct balance between achieving the benefits of scale and scope for pan-European challenges while reflecting local circumstances and priorities. Such is the underlying message of smart specialisation.

We are fully aware that smart specialisation is not a miracle cure but as in the search for new treatments and vaccines against COVID19 we should be guided by facts and lessons learned. Smart specialisation 'represents the most comprehensive policy experience on implementing innovation-driven progress in Europe [... $]^{26}$ and therefore provides a strong model on which to build a European comprehensive recovery plan involving regions and cities as key contributors. In addition, this policy approach can federate regions and cities with a European ambition. The implementation of the Green Deal (and the coming White Deal) ${ }^{27}$ and the Industrial Strategy requires political leadership in regions and cities to mobilise all resources, in particular, the most important: the hearts and minds of citizens.

Once the health crisis is over, the quest for a new world should begin with smart specialisation strategies playing their full part in aligned, smarter, place-based, and more sustainable development strategies in the EU.

\section{Bibliography}

Brondoni. S. M., \& Zaninotto, E. (2018). Overture de 'The 4th Industrial Revolution. Business Model Innovation \& Global Competition'. Symphonya. Emerging Issues in Management (symphonya.unimib.it), (2), 1-7.

http://dx.doi.org/10.4468/2018.2.01ouverture

Dorling D. (2020). The end of the Great Acceleration - and Why It's Good for the Planet, the Economy, and Our Lives, Yale University Press, April/May.

Fernandes C., Farinha L., Ferreira J., Asheim B. \& Rutten R. (2020): Regional Innovation Systems: What Can We Learn from 25 Years of Scientific Achievements? Regional Studies, July. http://dx.doi.org/10.1080/00343404.2020.1782878

Rodríguez-Pose A (2018). The Revenge of the Places that Don't Matter (and What to Do About It). Cambridge Journal of Regions, Economy and Society, 11(1), 189-209.

http://dx.doi.org/10.1093/cjres/rsx024 


\section{Notes}

1 'Never let a good crisis go to waste' attributed to Winston Churchill.

${ }^{2}$ Regions and sub-national entities.

${ }^{3}$ FoSS has already pointed out in its paper 'The Green Deal and Smart Specialisation' of the need to analyse the failure of the Lisbon Strategy to become the 'most competitive knowledge economy in the world' when embarking in a new ambitious European growth strategy for becoming 'the first climate neutral continent'. The fragmentation of innovation and transformation policies and resources, leading to subcritical mass and unnecessary duplications and persistent innovation gaps in national and regional innovation systems, was at the origin of the 'invention' of the smart specialisation approach towards a European Innovation System engaging all regions. Neglecting this policy experience (in the recent European policy documents) is therefore a policy failure that will hamper the necessary mobilisation of all resources. See http://www.efiscentre.eu/portfolio-item/friends-of-smartspecialisation

4 The revenge of the places that don't matter Andrés Rodríguez-Pose, 6 February 2018 https://voxeu.org/article/revenge-places-dont-matter

${ }^{5}$ Danny Dorling http://www.dannydorling.org/

${ }^{6} \mathrm{COM}(2019) 640$ final, Brussels, 11.12.2019

${ }^{7}$ A New Industrial Strategy for Europe COM (2020)102 final

${ }^{8}$ See http://www.efiscentre.eu/wp-content/uploads/2020/03/A-New-Industrial-Strategy-for-Europe Foss-Critique-170320.pdf

9 An initiative from an independent group of experts and practitioners concerned for the future directions of smart specialisation. The group's goal is to support the mainstreaming of Smart Specialisation as an instrument for strengthening the multi-level European innovation system. For more information see http://www.efiscentre.eu/portfolio-item/friends-of-smart-specialisation

${ }^{10}$ Next Generation EU:

https://ec.europa.eu/info/live-work-travel-eu/health/coronavirus-response/recovery-planeurope/pillars-next-generation-eu en

11 The Green Deal COM(2019) 640 final and Industrial Strategy COM(2020) 102 final

12 Strengthening its economic, social and territorial cohesion is one of the EU's main objectives. It dedicates a significant proportion of its activities and budget to reducing the disparities among regions, with particular reference to rural areas, areas affected by industrial transition, and regions which suffer from severe and permanent natural or demographic handicaps. See Articles 174 to 178 of the Treaty on the Functioning of the European Union (TFEU).

https://www.europarl.europa.eu/factsheets/en/sheet/93/economic-social-and-territorial-cohesion

${ }^{13}$ See Bjorn T. Asheim et al. (2019, 2020) Regional innovation Systems. Edward Elgar, Cheltenham, UK and Pia Lappalainen (ed) (2015) Orchestrating regional innovation ecosystems. Aalto University,

${ }^{14}$ Smart specialisation is an innovative approach that aims to boost growth and jobs in Europe, by enabling each region to identify and develop its own competitive advantages. Through its partnership and bottom-up approach, smart specialisation brings together local authorities, academia, business spheres and the civil society, working for the implementation of long-term growth strategies supported by EU funds.

https://ec.europa.eu/regional_policy/sources/docgener/guides/smart_spec/strength_innov_regions_e $\underline{\text { n.pdf }}$

For a much more complete overview go to the Smart Specialisation Platform:

https://s3platform.jrc.ec.europa.eu/what-is-smart-specialisation-

${ }^{15}$ See Friends of Smart Specialisation 'A New Industrial Strategy for Europe. What role for Smart Specialisation?'

http://www.efiscentre.eu/wp-content/uploads/2020/03/A-New-Industrial-Strategy-for-Europe_-FossCritique-170320.pdf

${ }^{16}$ Priority 1 has the specific objectives of: 1 . enhancing research and innovation capacities and the uptake of advanced technologies; 2. reaping the benefits of digitisation for citizens, companies and 
governments; 3. enhancing growth and competitiveness of SMEs; 4. developing skills for smart specialisation, industrial transition and entrepreneurship.

${ }^{17}$ Implementing Smart Specialisation: An analysis of practices across Europe, Caroline Cohen JRC Technical Report December 2019:

https://publications.jrc.ec.europa.eu/repository/bitstream/JRC118729/implementation_examples_fin al_pubsy.27.11.2019_vf_online.pdf

${ }^{18}$ For more information on this key aspect of smart specialisation see:

https://s3platform.jrc.ec.europa.eu/entrepreneurial-discovery-edp

19 See https://ec.europa.eu/growth/tools-databases/regional-innovation-monitor/report/annual/rimplus-2013-2014-final-report-european-regions-support-industrial-renaissance

${ }^{20}$ Born T. Asheim et al. (2019) Regional Innovation Systems. Edward Elgar, Cheltenham, UK

${ }^{21} \mathrm{See}$ https://s3platform.jrc.ec.europa.eu/en/thematic-platforms

22 https://s3vanguardinitiative.eu/

${ }^{23}$ For example, see the UK's senior bishop and principal leader of the Church of England, the Archbishop of Canterbury's Easter sermon: «After so much suffering, so much heroism from key workers $[\ldots]$ so much effort, once this epidemic is conquered here and round the world, we cannot be content to go back to what was before as if all is normal».

https://www.archbishopofcanterbury.org/speaking-writing/sermons/archbishop-canterburys-easter$\underline{\text { sermon }}$

24 See https://assets.ey.com/content/dam/ey-sites/ey-com/en_uk/topics/growth/regional-forecast2020-(feb)/the-economic-performance-of-english-regions-cities-and-towns.pdf

${ }^{25}$ See https://territorialthinkers.eu/home.html

${ }^{26}$ Implementing smart specialisation strategies (2016):

https://publications.jrc.ec.europa.eu/repository/bitstream/JRC102764/jrc102764_s3pfromdesigntoimplementationfinal(16-12-016)web.pdf

${ }^{27}$ Coronavirus: Von der Leyen plans "White Deal":

https://volksblatt.at/coronavirus-von-der-leyen-plant-white-deal/ 